\title{
Sharifah Halimah Alaydrus
}

\author{
Adib Rifqi Setiawan

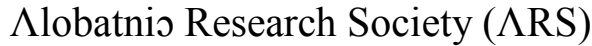 \\ Jl. Kudus - Colo km. 19, Pandak 001/003, Colo, Kudus, 59353, Indonesia \\ adibrifqisetiawan@gmail.com
}

\begin{abstract}
Sharifah Halimah Alaydrus was born in Indramayu, West Java on 2 April 1979 as 5th of 6 children of Usman Alaydrus and Nur Assegaf. She acquired her religious knowledge from some well-known NU (Nahdlatul 'Ulama) pondok pesantren (Islamic boarding schools or Islamic seminary): Darullughagh Wadda'wah in Bangil-Pasuruan, East Java; Pondok Pesantren at-Tauhidiyah in Tegal, Central Java; and Pondok Pesantren al-Anwar in Rembang, Central Java; then continued her study in Daruz Zahro, Tarim, Hadramawt. After graduating from Daruz Zahro Sharifah Halimah Alaydrus went back to Indonesia in 2002 and married in the same year. After her marriage, she start her $d a$ 'wa to some pondok pesantren in East Java. Since then, she has become very active in $d a$ 'wa not only in Jakarta, but also in other parts of Indonesia and abroad. Sharifah Halimah Alaydrus developing Ahbabuzzahro, that was opened in 2004, to share the expertise with the younger generation, which she and her juniors in Daruz Zahro are mentors, as part of her responsibility to equip young muslimât with religious knowledge and to bring them closer to their religion. Her talent and achievement in becoming students of Habib Umar bin Hafiz have made them authoritative voices both locally and transnationally. The case of Sharifah Halimah Alaydrus demonstrates not only the new visibility of such women in Indonesian public Islam, but also illuminates the significant role played by female Indonesian preachers in the global Muslim world.
\end{abstract}

Keywords: female preachers; da'wa; Halimah Alaydrus; Indonesian Islam;

\section{Introduction}

Bā'Alawī (a group of Haḍramī diaspora) migrants had settled in various parts of Southeast Asia by the eighteenth century (Alatas, 2011, p. 48; Ho, 2006; Mobini-Kesheh, 1999). The role of Bā'Alawi especially habā'ib (male descendants of the Prophet), has been significant in the Jakartan majelis ta'lim (a council or a meeting place for learning Islam, also spelled majlis taklim, majlis ta'lim, majelis taklim). In terms of da'wa (proselytisation), within Jakartan majelis ta'lim, Bā'Alawī have always had a special place in the hearts of Jakartan congregations. Hadramī diaspora have enjoyed prestige as the descendants of the Prophet (haba'ib) and because they have better religious knowledge than mainstream Jakartan Muslims. Jakartans have long respected the genealogical and religious eminence of Bā'Alawī. Throughout Jakarta's history, Indonesian 'ulamā' (Muslim scholars) including kyai kampung (lit. village Islamic scholar referring to Batavian 'ulamà') have collaborated with $h a b \bar{a} ' i b$ to spread Islam in Jakarta. Nowadays, the strong collaboration between the two can be seen from the establishment of Forum Ulama dan Habaib Betawi (The Forum of Batavian Religious Scholars and Habā'ib) which was formed in August 2008. 
Unfortunately, little is known about the role of sharā'if (female descendants of the Prophet) on Jakartan da'wa stages. In fact, studies of female preachers have been very limited to date (Marcoes, 1992; Burhanuddin, 2002; Abaza, 2004). This is ironic because women have always been the main participants in majelis ta'lim in Jakarta and elsewhere in Indonesia as Millie (2011) describes in West Java. Indonesia has recently witnessed the proliferation of da'wa, which has become a part of the business world through the presence of majelis ta'lim for upper class elites (Hoesterey, 2008; Hasan, 2009; Rudnyckyj, 2009), and the emergence of many young preachers who have come to the fore of Islamic $d a$ 'wa and become minor celebrities (Hasan, 2009, p. 239). These developments have not been isolated to male Muslims, but they are happening among female congregations also.

This article examines the emergence of a new generation of female preachers coming from the Bā'Alawi background within the context of transnational religious networks. The role of the majority of the older generation of sharā'if, such as the late Sharifah Lulu Alaydrus, the late Sharifah Seha Alatas, Sharifah Sukaenah binti Yahya and Sharifah Lulu al-Habsyi, has been significant in the development of Jakartan $d a$ 'wa. The new generation of shara 'if, however, as examined here and of which Sharifah Halimah Alaydrus is member, is different from the older generation and the majority of ustädhāt (female religious teachers) in Jakarta. These new sharā' if can be regarded as cosmopolitan ustādhät in terms of a general spatial definition of the cosmopolitan which is 'someone who moves across global space' (Stade, 2007, p. 232).

Sharifah Halimah Alaydrus is graduates from Yemeni educational institutions that train muslimāt in Shafi'ite forms of Islam and support the same Sufi path (tarīqa), tarīqa 'alawiyya (the Bā'Alawī path). ${ }^{1}$ Many studies of female preachers in Indonesia have ignored the transnational aspects of their quest for religious knowledge and the transformation of it. Through the activities of Sharifah Halimah Alaydrus, we can see not only the importance of Yemen, but also the importance of Indonesian Muslims in transmitting religious knowledge, not only to fellow Indonesians but also to Muslim communities in some parts of Hadramawt, especially in villages around Tarim.

Sharifah Halimah Alaydrus is the products of globalisation. She is active in the distribution of religious knowledge. Her role demonstrates the networks of religious learning of female descendants of the Prophet Muhammad. Martin Slama (2011, p. 241) has pointed out the importance of Hadramawt for Indonesians today in terms of the flow of religious knowledge, explained that $\mathrm{B}^{-}{ }^{‘} A l a w i \overline{~ r e g a r d e d}$ as an exemplary centre for Islamic learning, becomes more and more their spiritual homeland (again).

This qualitative work focus on analyses how people in Tarim (Hadramawt) have also acknowledged the capacity of female Indonesians to spread religious knowledge within the region. It is important to mention here the figure of Habib 'Umar b. Muhammad b. Hafiz, popularly known as Guru Mulia ${ }^{2}$ (Noble Teacher) by some of his students and followers in

\footnotetext{
${ }^{1}$ Tarīqa 'alawiyya created by Bā'Alawī scholar Muhammad b. 'Alī Bā'Alawī (d. 1255) in the thirteenth century (Alatas, 2011, p. 47; Knysh, 1999) (Alatas 2011:47; see also Knysh 1999). This tarīqa is mainly followed by Sayyid in Southeast Asia and is not exclusively for Ḥadramī communities (Abaza, 2004, p. 193).

${ }^{2}$ The use of term Guru often can be found in the designation of important scholar of Hadramī communities, for example: Habib Sayyid Idrus b. Salim al-Jufri, the founder of al-Khairaat in Palu was called as Guru Tua (the Old Teacher) (Slama, 2011, p. 246).
} 
Indonesia. The connection between Sharifah Halimah Alaydrus and Guru Mulia can be regarded as part of Guru Mulia's large family. Sharifah Halimah Alaydrus was the first student of an educational institution established by Guru Mulia, Daruz Zahro ${ }^{3}$. Guru Mulia is a teacher who always encourages his students to deliver what they have (religious knowledge) to people who need it. Sharifah Halimah Alaydrus is his students who were sent to villages in Hadiramawt to deliver religious messages. Guru Mulia himself is known as a preacher who is very active in delivering religious messages in every place he visits. The geography of Guru Mulia's proselytizing tours is quite impressive. Knysh (2001, pp. 406-7) describes Guru Mulia's da'wa activities has achieved and sustained his wide popularity by constantly travelling across the country and giving fiery public sermons and lectures at every stop.

Although majelis ta'lim exists in places other than Jakarta, many believe that Jakartan majelis ta'lim is the most popular type of gathering among Muslims living in Indonesia. Mona Abaza (Abaza, 2004, p. 179) supports this view and suggests that 'some would insist that the Majlis Ta'lims are a typical urban phenomenon which only exists in Jakarta'. In addition, in recent years Jakarta has witnessed a proliferation of majelis ta'lim. This has influenced some asātidh (male Muslim teachers) including haba ' $i b^{4}$ to move to Jakarta not only to attract Jakartan congregations, but also to increase their fame and financial rewards (Abaza, 2004, p. 180; Slama, 2011). Jakarta is chosen because up until now the most well-known shara 'if who have been active on the da'wa stage are Jakartans. Jakartans have not seen sharā'if from other regions who are able to appeal to their hearts and souls as Sharifah Halimah Alaydrus do.

The role of sharä'if has been mentioned in scholarly studies mostly in the context of their business, achievements in education, and organisational (al-Khairaat) domains (Slama, 2011, p. 252; 2012). The discussion on $d a$ 'wa and sharā' if mostly focuses on their active role in organising majelis ta'lim in their houses (Abaza, 2004, p. 179), not on their capacities as actual actors on the urban $d a$ 'wa stage. Therefore, this paper will contribute towards filling this gap by focusing on the role of sharā' if in the development of $d a$ 'wa in elsewhere.

\section{A Biography at Glance}

Sharifah Halimah Alaydrus is an example of the cosmopolitan Hadrami diaspora; her parents are muwallad (descendants of mixed marriages). She is 5th of 6 children of Usman Alaydrus and Nur Assegaf. Sharifah Halimah Alaydrus was born in Indramayu, West Java on 2 April 1979 and her husband is also from a Bā'Alawī family, Habib Ahmad b. Al-Haddar, although she once said in her ceramah that he is ustädh (male Muslim teacher).

\footnotetext{
${ }^{3}$ Daruz Zahro was founded in 1997 and managed by Darul Mustafa, its male wing. The building was completed and opened for public in 2001. Before its establishment there was one Indonesian sharifah who had been prepared to be part of the institution, Sharifah Amirah Jindan who is also a well-known female preacher from Bā'Alawī family.

${ }^{4}$ Some $h a b \bar{a}$ 'ib who migrated to Jakarta are: Habib Hasan bin Ja'far Assegaf the head of Nurul Mustafa, Habib Alwi b. Abdurrahman al-Habsyi of Raudhatul Habib and the late famous Habib Salim bin Jindan (Alatas, 2011, p. 66). Many well-known Jakartan kyai were the disciples of Habib Salim bin Jindan, such as Kyai Abdullah Syafi'i, the founder of as-Syafi'iyah (the most well-known Jakartan Islamic institution) (Murodi, 2002) and Kyai Thohir Rohili, the founder of At-Tahiriyah (another very wellknown Jakartan Islamic institution) (Rasyidah, 2002).
} 
Sharifah Halimah Alaydrus acquired her religious knowledge from some well-known NU (Nahdlatul 'Ulama) pondok pesantren (Islamic boarding schools or Islamic seminary). Her parents sent her to a pondok pesantren, Darullughagh Wadda'wah in Bangil-Pasuruan, East Java on 1991 when she was 12 years old. This pondok pesantren is owned by a Bā'Alawī family and was founded by the late Habib Hasan Baharun. Its current head is his son, Habib Zain b. Hasan Baharun. She continued her study in Pondok Pesantren at-Tauhidiyah in Tegal, Central Java, focused on tawhid (study of doctrine of the oneness of God). After 6 months there, she went to Pondok Pesantren al-Anwar in Rembang, also in Central Java, to pursue her focus on figh (Islamic jurisprudence). The most important educational institution that shaped not only her Islamic knowledge but also her personality, however, was Daruz Zahro in Yemen where she studied from late 1998 to 2002. She was the first student of Daruz Zahro. After four months of her enrolment, there were two other students enrolling at Daruz Zahro. Six months later the number of students was increasing. Four years after its establishment, Daruz Zahro had 140 students, and thirty of them were Indonesians. Since Sharifah Halimah Alaydrus was the first student of Daruz Zahro, her position is very special within its larger network.

After graduating from Daruz Zahro Sharifah Halimah Alaydrus went back to Indonesia in 2002 and married in the same year. She said that it marriage was based on Guru Mulia's instruction that can't rejected by her as her ta'dhim to her teacher. After her marriage, her husband brought her to some pondok pesantren in East Java to start her da'wa. In 2003 she had to go to Tarim to teach, but returned to Indonesia in the same year. Since then, she has become very active in da'wa not only in Jakarta, but also in other parts of Indonesia and abroad. Outside Jakarta, she also often gives talks in Bekasi, Depok, Bandung, Ternate, Ambon, Pontianak. She follows a fortnightly schedule for appearing in East Java and four times in a year she undertakes a week-long $d a$ 'wa tour visiting seventeen cities from Gresik to Banyuwangi. She also goes to Cirebon twice a year and she visits Malaysia and Singapore three to four times in a year. She has also successfully built al-Wafa, a network of female religious scholars who are graduates of Daruz Zahro and some from Al-Azhar University in Egypt. In Indonesia Sharifah Halimah Alaydrus is the only preacher associated with al-Wafa. Her da'wa tours in Malaysia and Singapore are also organised by al-Wafa or at least congregations from Singapore and Malaysia usually understand that when they want to invite Sharifah Halimah Alaydrus they need to contact al-Wafa, that will arrange more events for her while she is invited to preach in Singapore and Malaysia.

The presence of Sharifah Halimah Alaydrus signifies the emergence of a new wave of female preachers in Indonesia who are graduates of Yemeni institutions. Following Sharifah Halimah Alaydrus, there are other young preachers who graduated from Daruz Zahro, such as Ustādha Sharifah Samirah al-Habsyi, Ustādha Sharifah Zainunah Syafi'i (both these two are also graduates from the same pesantren as Sharifah Halimah, Darullughagh Wadda'wah in Bangil), Ustādha Sharifah Hanuna Alaydrus, Ustādha Sharifah Aisyah b. Syekh Abu Bakar and there are many more. Sharifah Halimah Alaydrus talent in $d a$ 'wa is acknowledged by her Yemeni institution and Guru Mulia. Not only did she study in Yemen, but she has also been allowed to teach there. She also taught in Oman during Ramadhan. According to Engseng Ho's concept of local cosmopolitans, Sharifah Halimah Alaydrus falls into the category of 'persons who, while embedded in local relations, also maintain connections with distant places. They thus articulate a relation between different geographical scales' (Ho, 2006, p. $31)$. 
Martin van Bruinessen (2011, p. 2) has pointed out that despite the fact that Indonesia is home to the largest Muslim community in the world, Indonesian Muslims 'do not play a role in global Muslim thought and action that is commensurate with their numbers'. He also pointed out that there is only very rarely were learned Indonesians invited to teach in the Middle East (Van Bruinessen, 2011, p. 6). Sharifah Halimah Alaydrus's da'wa on the Arabian Peninsula can be regarded as a rare opportunity for an Indonesian to actively engage the broader Muslim community. In addition, what makes Sharifah Halimah Alaydrus unique for her congregations is that she is also active in social media (Twitter, Facebook, Instagram, YouTube, and Blogger). She also writing for al-Kisah (the most popular magazine which focuses on Bă'Alawī in Indonesia), however, due to her tight schedule, she did not continue writing in al-Kisah. Sharifah Halimah Alaydrus is author her own book Bidadari Bumi: 9 Kisah Wanita Salehah, that offline version sold in Indonesia, Malaysia, and Singapore nor online version sell via Play Store, is about her spiritual journey meeting nine pious women who have inspired her personal and da'wa life (Alaydrus, 2010). She continued her authorship with Tutur Hati Halimah Alaydrus, Pilar Cahaya, and Muhasabah Cinta-that explains her experiences as an ustādh (Alaydrus, 2014; 2014; 2015).

\section{Responsibile to Equip Young Muslimāt}

Sharifah Halimah Alaydrus developing Ahbabuzzahro (literally, the lover of the Prophet's daughter Fātimah al-Zahrā) to share the expertise with the younger generation, which she and her juniors in Daruz Zahro are mentors. Ahbabuzzahro was built with a donation from a wealthy businesswoman, Sharifah Sidah Muhammad Alaydrus who owns a batik factory called Arjuna Weda. ${ }^{5}$

Ahbabuzzahro was opened in 2004 only for female students from the age of nine. More than 50 per cent of its students are of Hadramī background. Students attending this institution consider their teachers to be role models. Sharifah Halimah Alaydrus sees her activities in Ahbabuzzahro as part of her responsibility to equip young muslimāt with religious knowledge and to bring them closer to their religion.

In Indonesia, such tutoring is usually aimed at mastering secular subjects, such as mathematics, physics, and English. Ahbabuzzahro, however, focuses on mastering Islamic knowledge. The subjects being taught are: hadith (tradition or sayings of the Prophet Muhammad), tawhìd, fiqh, bahasa Arab (Arabic languge), and sìrah (the history of the Prophet and His pious companions). The texts used in these courses are also adopted from Daruz Zahro and some books written by scholars in Haḍramawt, including the works of Guru Mulia.

Since the majority of teachers are graduates of Daruz Zahro, they also directly and indirectly introduce the culture of Daruz Zahro and the Islamic lifestyle of Hadramawt, e.g. some teachers and students wore the face-veil. Ustādha Sharifah Samirah al-Habsyi, one of the teachers, explained that they do not ask students to wear the face-veil, but teachers graduated from Daruz Zahro in this tutoring course wear the face-veil, so they have indirectly introduced Daruz Zahro culture.

\footnotetext{
${ }^{5}$ Sharifah Sidah Muhammad Alaydrus can be regarded as one of the very successful female entrepreneurs in Indonesia. The products of her batik business, Arjuna Weda, can be founded in well-known shopping centers, such as Metro, Centro, Sun, and Yogya (Slama, 2012, p. 322).
} 
Sharifah Halimah Alaydrus is very important to many of these teenagers. Her success as a lovable and talented preacher has made her a role model for many of these young Hadramī teenagers and many of her young congregation, in general. Aisha, ${ }^{6}$ a 24 -year old, in her congregation about Sharifah Halimah Alaydrus says:

"Ustādha Sharifah Halimah Alaydrus is my idol. She is very smart. I love the way she gives a talk. I always pray to God that someday I can follow her step. I really want to be like her."

The presence of Sharifah Halimah Alaydrus on the Jakarta da'wa stage has made many young Jakartan Muslims to feel that they have found a new idol. Hafsha a 25-year old university student, says:

"The presence of Ustādha Sharifah Halimah Alaydrus is like a gift from God. She is different from other ustädhāt that we have in Indonesia. She is young, beautiful, and talented. Most of all she is coming from the family of the Prophet Muhammad. I think she is the only sharifah who has such a huge talent in delivering Islamic messages."

Hafsha's comments on Sharifah Halimah Alaydrus's talent are echoed by other older women. Ibu Khadijah, 55 years old, for example, says:

"Her talk is amazing. Before, I never found a young and old ustādhāt who could preach as good as her. I will definitely recommend my friends who have a majelis ta'lim to invite her to give a talk in their events."

Sharing the same impression of Sharifah Halimah Alaydrus's talent, Ustādha Marzukoh, a 62-year-old organiser of a majelis ta'lim in South Jakarta, says:

"Her ceramah is amazing. I will invite her to give a maulid ceramah (speech on maulid celebration) at my majelis ta'lim. I hope her agenda is still free for my invitation."

Ustādha Marzukoh and many other ustādhāt who listened to her speech had a similar impression. They were competing with each other to invite Sharifah Halimah Alaydrus. However, she is extremely busy. She says:

"My schedule is very tight. Those who want to invite me must be ready to contact me at least three months ahead of the event. During the maulid and isra' mi'raj (the celebration of the Ascension of the Prophet Muhammad), the request to invite me must be made even earlier."

\section{Understanding the Needs of Muslimāt}

As a talented gendered public speaker for female congregations, Sharifah Halimah Alaydrus knows how to deliver her message effectively. She knows how to speak to a variety of audiences. In one event, her audience's backgrounds can be very diverse, from ustāadhāt who have majelis ta'lim (a mainstream congregation consists of women between 40 and 60 years old), teenagers (senior and junior high school students) to primary school-age children.

\footnotetext{
${ }^{6}$ All the names of the informants have been changed (except those of sharā'if, habā'ib, and asātidhāt) to preserve confidentiality.
} 
Sharifah Halimah Alaydrus has her own trademark style of preaching, namely by using the story of the life of the Prophet Muhammad and His pious companions as her presentation aid. She says:

"Stories for most of my female congregants are easier to understand. Stories can also prevent boredom. In addition, I think when we use stories in our talk then we do not only convey the knowledge but also deliver the seeds of love to the hearts of our congregations; the love to God, the Prophet Muhammad, and pious Muslims."

The term presentation aid refers to what Anthony G. King (1992, p. 72) points out as 'any aid which the speaker uses to help the audience understand or remember the presentation'.

There are many ustāadhat who are successful in passing on knowledge about praying, such as its how to do it and the elements that make the prayer acceptable and unacceptable. Unfortunately, there are only a few of these preachers who can transfer the feeling of how to understand the prayer and the hopes of the person after the prayer is done. Sharifah Halimah Alaydrus believes that the art of delivering a speech is not only a matter of transferring knowledge, but also transferring feeling. She explains:

"I think one important point in delivering a speech is not only to pass the knowledge but also to touch the hearts of the audiences."

Sharifah Halimah Alaydrus added:

"You know, the age range of my congregations is diverse. For me, the story is proven to be easier to accommodate the needs of these congregations. I know that women from diverse age groups love to hear the story."

Ibu Dayna, 49 years old, shares her feeling on the effectiveness of listening to it:

"I like attending Ustādha Sharifah Halimah Alaydrus's talk, especially listening to her story. I can understand better the context of her ceramah through her story."

In personal, the intonation of Sharifah Halimah Alaydrus voice is very interesting. It is different from other styles of native preachers in Indonesia, such as the most famous Mamah Dedeh who use quite a strong voice and a high tone. Sharifah Halimah Alaydrus has a great passion to tell the story. Her speech can make shed my tears. I hope some time can sowan to her ndalem or she arrives to my hometown that make me can attend her talk.

\section{Representing Good Muslimāt}

The story of the life of Hadramī often demonstrates how women had been secluded at home. This kind of gender order was then challenged, especially since the late colonial times (Slama, 2012, p. 319). Huub de Jonge (2004, p. 380), while describing the life of a journalist and politician Abdul Rahman Baswedan, for example, explained how 'women seldom ventured outside the house, and the daily necessities were usually bought by husbands or sons'. Besides being secluded, strict gender segregation is also often mentioned in discussions of women of Bā'Alawi families. Urike Freitag pointed out that 'women formed part of the varying strata but in many contexts constituted a separate group because of the relatively strict gender segregation, notably in urban context' (Freitag, 2003, p. 41). Sharifah Halimah Alaydrus understand issues relating to women and their mobility. It is important to note that she did not think that being part of a Bā'Alawi family made her secluded from public spaces. This phenomenon can also be a result of social change, as older generations of women of Bā'Alawī families were more secluded. 
Slama (2012) in his work on Hadramī women and gender relations has pointed out some progressive transformations in relation to gender relations and the agency of these women. Gendered hierarchy in domestic sphere can be seen less obvious in the life of Sharifah Halimah Alaydrus. She and her husband are actively working in the public sphere. As mentioned earlier, her schedule is very tight, inside and outside Jakarta. Usually she go out from her ndalem early in the morning, always try her best to be at home from 8 p.m. onwards. Everyone who want meet up in her ndalem may at 9 p.m., if she want. What can be seen here is that she gets full support from her husband to be active in gendered public sphere. For a family that upholds religious values strictly, like that of Sharifah Halimah Alaydrus who is also a religious preacher, this kind of support can be regarded as quite special. For Haḍramī women who do not uphold strictly to their religious values, however, this kind of support might be much easier to obtain.

$B \bar{a} \bar{a}^{‘}$ Alawi are very strict in preserving the values and norms relating to idealised and hierarchical understandings of gender. The idealised image of sharifah is reflected in the term bint al-bayt (girl of the house) or rabbatu al-bayt (housewife) referring to those who refrain from mobility, such as not going to the market. Sharifah Halimah Alaydrus is also aware of these assumptions, explaines that for her what might be adopted in Hadramawt cannot be adopted in Jakarta. Although she was educated from Yemen, she has embodied some aspects of gender concepts in Indonesia. It is fits Martin Slama's (2012, p. 314) argument that 'Hadhrami concepts of the public and domestic encountered local and governmental gender regimes, and experienced considerable transformations in conjunction with social changes that affected Indonesia after its independence'. In Hadramawt we may say that women should be inside their houses, have to limit their mobility. However, here is different. In Indonesia, as Nong Darol Mahmada (2007) explained, it is very common to see women who are working to support the life of their family. Therefore we have to be wise in distinguishing what is part of Islamic teaching and what is part of the tradition.

The activities of Sharifah Halimah Alaydrus explained that Indonesian cultures should be respected demonstrates her cosmopolitan orientation. She also recognises that women not leaving the house is a part of Arab tradition rather than strictly relating to Islam. Pnina Werbner (1999, pp. 19-20) elaborates that cosmopolitans as those who 'familiarise themselves with other cultures and know how to move easily between cultures'. Sharifah Halimah Alaydrus, who respects the host culture, demonstrates that she is a cosmopolitan Muslim, who consider herself as belonging not only to the Hadramawt community, but also to other communities. Werbner $(1999$, p. 34) also has emphasised this view, stating that cosmopolitanism 'does not necessarily imply an absence of belonging but the possibility of belonging to more than one ethnic and cultural localism simultaneously'.

Although Sharifah Halimah Alaydrus do not limit her mobility, she strive to be careful in managing her mobility in order not to violate the teachings of Islam as she understand them. She have to make sure that their mobility does not create fitna (disgrace) ${ }^{7}$ and that when she is away she can still guard their modesty. This is done by wearing proper Muslim dress, which for Sharifah Halimah Alaydrus means wearing a black 'abāya (black head-to-toe wrap covering all of a woman's body) and the cadar. I emphasises that women should maintain their hayā' (shyness) and 'iffa (purity, chastity, and virtue), and when they have these two

\footnotetext{
${ }^{7}$ Fitna refers to infatuation, riot, trial, scandal, and disgrace. In the context of the link between the outward appearance of women and fitna, it means that improper female dressing can provoke sexual temptation which threatens order and stability.
} 
characteristics then they will strive to adjust their lives according to Islam. These two traits provide women with the means to save them from the temptation of following the wrong path. Both of these preachers also preach only to same-sex $t a$ 'lim. This is different from most female Jakartan preachers who preach to both male and female congregants.

One important aspect that has made her able to be active in $d a$ 'wa is the support from her husbands. It cannot be denied that some haba 'ib might be reluctant to allow their wives to be active in the public sphere. Although Habib Ahmad b. Al-Haddar, her husband, is not a da' $i$, he gives his permission for her to be active in da'wa. Sharifah Halimah Alaydrus even told that the first one asked her to records her voice for $d a$ 'wa was her husband. As the support to Sharifah Halimah Alaydrus also the reponsibility as a husband, Habib Ahmad b. Al-Haddar is the one who organises her schedules and who connects her to important male ulama (religious scholars) in Indonesia.

Sharifah Halimah Alaydrus who has a tight schedule of public activities has her own checklists to make sure that she does not violate Islamic teachings as she understands them. First, when she has to preach without her husband accompanying her she will have female assistants, usually Maryam. Second, if she has to preach in an open public space like a mushalla (a small mosque) or a mosque, then she always makes sure that the place is covered with curtains so men cannot see her face, because she takes her cadar off during her talk. The last item on the checklist relates to taking her picture. She does not want her picture to be taken, especially when she does not wear the cadar. One thing that is evident from the behaviour of Sharifah Halimah Alaydrus is that although sher strive to present herself in a way that the majority of Indonesians might consider too strict, such as wearing 'abaya and cadar, she never push her congregations to follow them in adopting this form of dress. She understand that she live in a cosmopolitan environment where she have to engage, respect, and mingle with Indonesian Muslim communities on their own terms.

\section{Conclusion}

This article examined the role of two sharā'if in the development of $d a$ 'wa and networks of female religious learning. What can be seen here is that the Hadrami actors behind the transnational dissemination of religious learning do not come only from male $h a b \bar{a}$ ' $i b$, but also from female sharā'if. This network has bound together not only Hadramī communities, but also Muslim communities across borders, such as in the case of Sharifah Halimah Alaydrus and al-Wafa, the network that she has established with graduates from Daruz Zahro in Yemen and Al-Azhar in Egypt. The network has provided a web of links between female preachers across borders which can be regarded as one of a kind. This article has not focused on the figure of Guru Mulia, however, he is important for Sharifah Halimah Alaydrus and her followers. She have been connected with Guru Mulia and his centre of religious learning in Tarim, Haḍramawt. Sharifah Halimah Alaydrus is teachers and scholars of Haḍramī origin and have brought with her texts and teachings originating in Haḍramawt in which the works of Guru Mulia are the main source of reference, on the same case in Zanzibar (Bang, 2007).

The preachers in this study represent a new generation of talented shara 'if whose irresistible charisma can attract young congregations. One challenge for most Jakartan muballigha (female preachers) is making sure their message is listened to by the younger generation. Many young Indonesian Muslims from secular academic backgrounds are drawn to more conservative Muslim organisations and movements, such as Salafi and Tarbiyah movements. Sharifah Halimah Alaydrus have successfully attracted young followers who have strong 
religious backgrounds (pondok pesantren or madrasa and Islamic state university students) as well as those who have secular backgrounds (state university students). This diversity is rarely found within the ta'lim of well-known Jakartan muballigha. What can be seen here is that Sharifah Halimah Alaydrus understand the needs of her audiences. In addition, the fact that she is relatively young helps her relate to the lives of the younger generation. Her thorough understanding of Islam, and the chain of religious knowledge of which she is part, has also strengthened her position as profound preacher. The presence of Sharifah Halimah Alaydrus is a response to the demand of Jakartan congregations who long to have female preachers who have the same qualifications as many haba'ib in Indonesia. These include having the same experiences of learning Islam in Haḍramawt and having the same thorough Islamic understanding as $h a b \bar{a} ' i b$.

Sharifah Halimah Alaydrus, as successful cosmopolitan preacher, have a significant role in strengthening the part that Hadramī play in the process of transformation of religious knowledge. Having been inspired by her success, many young Haḍramī and non-Haḍramī aspire to study in Tarim in Haḍramawt. For example, my friend in pondok pesantren MUSYQ Kudus Ali Ahmad Qosim Bāfaqīh (Ḥaḍramī) and in madrasah MA NU TBS Kudus Ahmad Baihaqi (non-Haḍramī), prefer to go to Tarim rather than Cairo to pursue higher religious education after completing their schooling in Indonesia. This article also demonstrates the strong position of Haḍramawt for Haḍramī in Indonesia today, while at the same time the recognition of people in some parts of Hadramawt of the capacity women in Indonesia have in $d a$ ' $w a$ activities. The success of Sharifah Halimah Alaydrus has brought us to see the increasing role of Daruz Zahro in the development of $d a$ 'wa not only in Jakarta but also elsewhere in Indonesia.

This article fits Slama's (2012) argument about the transformation of the agency of sharā'if from colonial times to presentday Indonesia. What can be seen is the expansion of the agency of sharā'if who are active in da'wa. The Hadramī women studied by Slama (2012) who are active as businesswomen might have embedded the notion of being in public in a more progressive way. Sharā' 'if who are active in preaching are more restricted. They still maintain some aspects of strict religious teachings, such as wearing the 'abāya and cadar and preaching only to the same-sex $t a^{\prime}$ 'lim. This attitude, however, should not be seen as a counter towards progressive ideas of the expansion of Hadramī women's agency. It should be seen as their efforts to negotiate their position as pious muslimāt who uphold Islamic teachings carefully and have a progressive understanding of the position of women. Sharifah Halimah Alaydrus still strive to comply with the gender ideology that she believe as part of Islamic teachings, while at the same time to be open-minded to the gendered norms of the community where they live. Therefore, their agency can be seen in this part of the public sphere.

\section{Acknowledgment}

This article is a gift for Sharifah Halimah Alaydrus as my current role model to her 41th birhday on 2 April 2020. She is amazing inspiring and motivating my learning nor become shaping my mindset. 


\section{References}

Abaza, M. (2004). Markets of faith: Jakartan da'wa and Islamic gentrification. Archipel, 67, 173-202.

Alatas, I. F. (2011). Becoming Indonesians: the Bā'Alawi in the interstices of the nation. Die Welt des Islams, 51, 45-74.

Alatas, I. F. (n.d.). "Gold and silver, branded horses and welltilled land" gender and H aḍramī migration. http://citizenhistorian.com/wp-content/uploads/2008/03/almihdar-for-pdf3-footnotes.pdf.

Alaydrus, S. H. (2010). Bidadari Bumi. 9 Kisah Wanita Salehah. Jakarta Pusat: Wafa Production.

Alaydrus, S. H. (2014). Pilar Cahaya. Jakarta Pusat: Wafa Production.

Alaydrus, S. H. (2014). Tutur hati Halimah Alaydrus: dalam kata, kalimat, bait dan lembar. Kuala Lumpur: Inteam Publishing.

Alaydrus, S. H. (2015). Muhasabah Cinta. Jakarta Pusat: Wafa Production.

Bang, A. K. (2007). Teachers, scholars and educationists: the impact of Hadiramī- 'Alawī teachers and teachings on Islamic education in Zanzibar ca. 1870-1930. Asian Journal of Social Science, 35, $457-71$.

Burhanuddin, J. (2002). Ulama Perempuan Indonesia. Jakarta Pusat: Gramedia Pustaka Utama.

de Jonge, H. (2004). Abdul Rahman Baswedan and the emancipation of the Hadramīs in Indonesia. Asian Journal of Social Science, 32(3), 373-400.

Freitag, U. (2003). Indian Ocean Migrants and State Formation in Hadiramawt. In Reforming the Homeland. Leiden: Brill.

Hasan, N. (2009). The making of public Islam: piety, agency, and commodification on the landscape of the Indonesian public sphere. Cont Islam, 3, 229-50.

Ho, E. (2006). The Graves of Tarim. Genealogy and Mobility across the Indian Ocean. Berkeley: The University of California Press.

Hoesterey, J. (2008). Marketing morality: the rise, fall and rebranding of Aa Gym. In Expressing Islam: Religious Life and Politics in Indonesia (pp. 95-112). Singapore: Institute of Southeast Asian.

Jacobsen, F. F. (2007). Introduction. Asian Journal of Social Science, 35, 402-04.

King, A. G. (1992). Legal Practice Handbook: Effective Communication. Exeter: Blackstone Press.

Knysh, A. (1999). The sada in history: a critical essay on Ḥ aḍramī historiography. Journal of the Royal Asiatic Society, 9(2), 214-22.

Knysh, A. (2001). The tariqa on a Landcruiser: the resurgence of Sufism in Yemen. Middle East Journal, 55(3), 399-414.

Mahmada, N. D. (2007, April 7). Peraturan Daerah Syariat dan Perempuan. Koran Tempo.

Marcoes, L. (1992). The female preacher as a mediator in religion: A case study in Jakarta and West Java. In Women and Mediation in Indoensia (pp. 203-28). Leiden: KITLV Press.

Millie, J. (2011). Islamic preaching and women's spectatorship in West Java. The Australian Journal of Anthropology, 22, 151-69.

Mobini-Kesheh, N. (1999). The Hadrami Awakening: Community and Identity in the Netherlands East Indies, 1900-1942. Ithaca.

Murodi. (2002). Tutty Alawiyah: pengembang masyarakat lewat majlis taklim. In Ulama Perempuan Indonesia (pp. 197-227). Jakarta Pusat: Gramedia Pustaka Utama.

Rasyidah, I. (2002). Suryani Thahir: perintis pengajian perempuan. In Ulama Perempuan Indonesia (pp. 174-96). Jakarta Pusat: Gramedia Pustaka Utama.

Rudnyckyj, D. (2009). Spiritual Economies: Islam and neoliberalism in contemporary Indonesia. Cultural Anthropology, 24(1), 104-141.

Shahab, Y. Z. (n.d.). Endogamy and multiculturalism: the case of Hadrami in Indonesia'. http://rihlah.nl.sg/Paper/Yasmine\%20Shahab.pdf.

Slama, M. (2011). Translocal networks and globalisation within Indonesia: exploring the Hadhrami diaspora from the Archipelago's North East. Asian Journal of Social Science, 39(2), 238-57.

Slama, M. (2012). "Coming down to the shop": trajectories of Hadhrami women into Indonesian public realms. The Asia Pacific Journal of Anthropology, 13(4), 313-33.

Stade, R. (2007). Methodological cosmopolitanism in Anthropology. Social Anthropology, 15(2), 232-34.

Van Bruinessen, M. (2011). Indonesian Muslims and Their Place in the Larger World of Islam. The 29th Indonesia update conference (30 September-2 October). Canberra: Australian National University.

Werbner, P. (1999). Global pathways, working class cosmopolitans and the creation of transnational ethnic worlds. Social Anthropology, 7(1), 17-35. 